\title{
PHYSICAL CHARACTERISTICS, SENSORY EVALUATION, AND AMINO ACID CONTENT OF POWDERED OVER FERMENTED MLANDING TEMPEH
}

\author{
[Karakteristik Fisik, Evaluasi Sensoris, dan Kadar Asam Amino Bubuk \\ Tempe Mlanding Over Fermented]
}

\author{
Asri Nursiwi ${ }^{\star}$, Dwi Ishartani, Ardhea Mustika Sari, and Nur Ayu Istiqomah \\ Department of Food Science and Technology, Universitas Sebelas Maret, Surakarta
}

Received July $2^{\text {nd }} 2020$ / Accepted June $27^{\text {th }} 2021$

\begin{abstract}
Mlanding tempeh is non-soybean tempeh made from ripe lamtoro (Leucaena leucocephala) seed. In Wonogiri, an area in Indonesia, over fermented mlanding tempeh (OFMT) is often used as a seasoning for traditional food since it produces a special taste. OFMT is also dried to extend the shelf life, making it easier to use as a seasoning. This research aims to study the physical characteristics, sensory evaluation, and amino acid content of powdered over fermented mlanding tempeh (POFMT). The drying of the OFMT used a cabinet dryer with variations in drying temperatures of 55,60 , and $65^{\circ} \mathrm{C}$ for eight hours. Then, it was mashed and sifted to obtain POFMT. The obtained powder was then analyzed for its physical characteristics in yield, water absorption capacity, solubility, bulk density, sensory evaluation with the hedonic test, and amino acid content. This study found that different drying temperatures significantly affected the yield and water absorption but did not significantly affect the solubility and bulk density. The yield values varied between 7.06-12.92\%; water absorption capacity varied between 0.36-0.55 g/g; solubility varied between $36.45-41.33 \%$; bulk density varied between $0.38-0.42 \mathrm{~g} / \mathrm{mL}$. The sensory evaluation results showed that the panelists' preference for POFMT with variations in drying temperature was not significantly different. In addition, the amino acid content of POFMT varied between $0.99-5.43 \%$ (db), with the highest levels being glutamic acid and aspartic acid.
\end{abstract}

Keywords: amino acid, drying, mlanding tempeh, powdered over fermented mlanding tempeh, seasoning

\begin{abstract}
ABSTRAK
Tempe mlanding merupakan tempe yang terbuat dari biji lamtoro tua. Di Wonogiri, tempe mlanding yang sudah mengalami fermentasi lanjutan (over fermented) seringkali dimanfaatkan sebagai bumbu berbagai makanan tradisional. Tempe mlanding over fermented ini dikeringkan untuk memperpanjang masa simpan dan mempermudah penggunaannya sebagai bumbu. Penelitian ini bertujuan untuk mempelajari karakteristik fisik, evaluasi sensori, serta kadar asam amino dari bubuk tempe mlanding overfermented. Pengeringan tempe mlanding over fermented ini menggunakan cabinet dryer dengan variasi suhu pengeringan 55, 60, dan $65^{\circ} \mathrm{C}$ selama 8 jam. Kemudian dihaluskan dan diayak sehingga diperoleh bubuk tempe mlanding over fermented. Bubuk yang diperoleh, dianalisis karakteristik fisik yang berupa rendemen, daya serap air, kelarutan, bulk density, evaluasi sensori dengan uji kesukaan, dan kadar asam amino. Pada penelitian diperoleh hasil bahwa suhu pengeringan yang berbeda memberikan pengaruh yang nyata terhadap rendemen dan daya serap air dan tidak memberikan pengaruh yang nyata terhadap kelarutan dan bulk density. Nilai yield bervariasi antara 7,06-12,92\% dan daya serap air bervariasi antara 0,36-0,55 g/g, sedangkan untuk kelarutan bervariasi sebesar 36,45-41,33\% dan bulk density bervariasi antara 0,38-0,42 $\mathrm{g} / \mathrm{mL}$. Hasil dari evaluasi sensori menunjukkan bahwa kesukaan panelis terhadap bubuk tempe mlanding over fermented dengan variasi suhu pengeringan tidak berbeda secara nyata. Kadar asam amino bubuk tempe mlanding over fermented bervariasi antara 0,99-5,43\% (db), dengan kadar yang paling tinggi adalah asam glutamat dan asam aspartat.
\end{abstract}

Kata kunci: asam amino, bubuk tempe mlanding overfermented, bumbu, pengeringan, tempe mlanding

\footnotetext{
The manuscript has been presented in the $16^{\text {th }}$ ASEAN Food Conference 2019 , October $15^{\text {th }}-18^{\text {th }}, 2019$, Bali-Indonesia
}

${ }^{*}$ Corresponding Author: E-mail: asrinursiwi@staff.uns.ac.id 


\section{INTRODUCTION}

Lamtoro (Leucaena leucocephala) is included in the legume family Fabaceae (Nwokocha and Williams, 2012) that grows well in tropical countries such as Indonesia (Zayed et al., 2018). The protein content in lamtoro seeds is high (24.5-46\%) (Verma et al., 2018). In Gunungkidul, Wonogiri, and Pacitan, regions in Indonesia, ripe lamtoro seeds are processed into lamtoro tempeh (Nursiwi et al., 2018). Traditionally, the manufacture of lamtoro tempeh uses laru or usar as an inoculum. Laru or usar is an inoculum in tempeh fermentation consisting of a group of mold spores. Rhizopus oryzae and Rhizopus oligosporus were found in the traditional tempeh inoculum (Duniaji et al., 2019). Some people call lamtoro tempeh as mlanding tempeh, in Wonogiri. It is non-soybeans tempeh, made from ripe lamtoro seeds through fermentation using usar. Usar is a tempeh inoculum that contains Rhizopus sp. and some microbial contaminants (Triyono et al., 2017). During 36 hours of fermentation of lamtoro seeds using commercial inoculum, there is an increase in protein content and dissolved protein levels, from $26.48 \%(\mathrm{db})$ to $34.39 \%(\mathrm{db})$ and from $3.92 \%(\mathrm{db})$ to $7.28 \%$ (db), respectively (Nursiwi et al., 2018). In the fermentation of soybean tempeh, the longer the fermentation time, the higher the amino acid content. It is resulted from protein hydrolysis by the activity of $R$. oligosporus. The highest free amino acids are produced during 24 to 72 hours of fermentation (Handoyo and Morita, 2006).

In the Wonogiri area, mlanding tempeh has undergone further fermentation or referred to as over fermented mlanding tempeh, which is fermented 1-5 days longer than fresh mlanding tempeh. The local community adds it as a traditional food seasoning, such as for making sambal tumpang. It is the same as some communities in Java that utilize over fermented soybean tempeh as a seasoning for various traditional foods. This continued fermentation increases the volatile component, contributing to the special flavor produced. Increased glutamic acid and stronger flavor intensity show the potential of over fermented tempeh as a seasoning (Wijaya and Gunawan-Puteri, 2015). In 50 to 90 hours of fermentation, the mold growth decreases and is replaced by bacteria so that amino acids are degraded, and ammonia is formed, which has a characteristic pungent odor (Gunawan-Puteri et al., 2015; Hassanein et al., 2015). Pungent odor is also produced from fat hydrolysis. The over fermented tempeh is usually fermented for longer than normal tempeh, about 2-5 days longer (Hassanein et al., 2015).

As a seasoning, over fermented tempeh is usually used in a fresh form. The over fermented tempeh, if not immediately used, will change. It is caused by fermentation that still continues, especially the flavor produced. In addition, the shelf life of over fermented tempeh is limited, only three days, after which the product becomes unsuitable for consumption with very soft textures, darker colors, and very strong odor (Syahrial and Muchalal, 2001). In this case, one method that can be used to stop the continued fermentation is the drying process. The drying process followed by grinding into powder can extend shelf life and facilitate the use of powdered tempeh as a seasoning more easily (Andriani and Nurhartadi, 2014).

One important factor in drying is the drying temperature. Drying over fermented soybean tempeh at temperatures of 55,60 , and $65^{\circ} \mathrm{C}$ resulted in higher drying temperature, lower yield and bulk density, and higher water absorption. While the solubility increased when the temperature increased, the solubility was constant at 60 and $65^{\circ} \mathrm{C}$. The results also showed that the drying temperature influenced the physical characteristic (Andriani and Nurhartadi, 2014). Therefore, this study intended to study the physical characteristics, sensory evaluation, and amino acid content of powdered over fermented mlanding tempeh (POFMT), dried using a cabinet dryer.

\section{MATERIALS AND METHOD}

\section{Materials}

The ripe lamtoro seed (brown color) and the traditional inoculum were obtained from a small industry that produced mlanding tempeh in Wonogiri, Indonesia.

\section{POFMT sample preparation}

The ripe lamtoro seeds $(4 \mathrm{~kg})$ were boiled (first boiling) by adding $500 \mathrm{~g}$ of ash into ten liters of water for two hours. Then, the hull was separated from the lamtoro seed. Afterward, the seed was soaked for 24 hours (changing the water after 15 hours of soaking), with the ratio between the water and seed being 4:3. Next, the lamtoro seeds were boiled (second boiling) for two hours, drained and cooled down (Nursiwi et al., 2018). After that, it was inoculated with traditional inoculum $(5 \% \mathrm{w} / \mathrm{w})$, packaged, and incubated for 60 hours at room temperature. The resulting OFMT was then dried using a cabinet dryer at various temperatures of 55,60 , and $65^{\circ} \mathrm{C}$ for eight hours. Then, it was powdered and sieved with an 80-mesh siever.

\section{Analysis of POFMT}

The POFMT was analyzed for physical characteristics, namely yield using method described by Andriani et al. (2013), bulk density using the method described by Kumalasari et al. (2015), solubility 
using method described by Buwono et al. (2018), water absorption capacity using the method described by (Ariyantoro et al., 2016), and amino acid content using UPLC Waters $\mathrm{H}$ Class with Photodiode Array Detector (PDA) and column $\mathrm{C} 18$ (Waters, 2012). Meanwhile, the sensory evaluation employed a 7-points hedonic scale ( $1=$ dislike very much; $7=$ like very much). Then, 30 untrained panels were asked to rate their preferences for color, aroma, taste, and overall (Marand et al., 2020).

\section{Data analysis}

The data (three sample replicates) were statistically analyzed using one-way analysis of variants at a significance level of $5 \%(\alpha=0.05)$ to determine the effect of differences in drying temperatures on the POFMT physical characteristic, amino acid content, and sensory evaluation. If there were differences, it was followed by analysis using the Duncan Multiple Range Test (DMRT) at a significance level of $5 \%$.

\section{RESULTS AND DISCUSSION}

\section{Physical characteristic}

Physical characteristics analyzed in POFMT were yield, water absorption capacity, solubility, and bulk density. The results of physical characteristics are shown in Table 1.

\section{Yield}

The yield calculation was based on a comparison between the powder's final weight and the tempeh's initial weight before drying. According to Table 1, the yield of POFMT with the drying temperature of $55^{\circ} \mathrm{C}$ was significantly different from that of $65^{\circ} \mathrm{C}$. The yield of the POFMT with the drying temperature of $55^{\circ} \mathrm{C}$ was significantly higher than the drying temperature of $65^{\circ} \mathrm{C}$. Meanwhile, POFMT with the drying temperature of $55^{\circ} \mathrm{C}$ was not significantly different from that of $60^{\circ} \mathrm{C}$, and POFMT with the temperature of $60^{\circ} \mathrm{C}$ was not significantly different from that of $65^{\circ} \mathrm{C}$. The yield of POFMT with the drying temperatures of 55,60 , and $65^{\circ} \mathrm{C}$ was $12.92,10.37$, and $7.06 \%$, respectively. These results indicate the same trend with the drying jack bean (Canavalia ensiformis) tempeh into tempeh flour. The yield of drying jack bean tempeh using a tem- perature of $55^{\circ} \mathrm{C}$ was significantly higher than drying at $65^{\circ} \mathrm{C}$ (Affandi et al., 2020). In this regard, the yield value of a process decreases if the drying temperature increases. The drying process causes the moisture content of the material to be reduced and leads to a decrease in yield (Purbasari, 2019).

\section{Water absorption capacity}

Water absorption capacity is the ability of the powder to absorb water. Particle size, moisture content, and differences in chemical content and material affect water absorption (Ntau et al., 2017). According to Table 1, the water absorption capacity of POFMT with a drying temperature of $55^{\circ} \mathrm{C}$ was significantly different from that of $65^{\circ} \mathrm{C}$. In contrast, the drying temperature of $60^{\circ} \mathrm{C}$ was not significantly different from that of 55 and $65^{\circ} \mathrm{C}$. The water absorption capacity of POFMT dried with the drying temperature of 55,60 , and $65^{\circ} \mathrm{C}$ were $0.55,0.45$ and $0.36 \mathrm{~g} / \mathrm{g}$, respectively. These results showed the same with research conducted by Affandi et al. (2020) in making jack bean tempeh flour. In their study, the water absorption capacity of the flour resulted in the drying temperature of $55^{\circ} \mathrm{C}$ being significantly higher than the drying temperature of $65^{\circ} \mathrm{C}$. In this case, water absorption is related to hydrophilic molecules, especially protein and carbohydrates, so it is influenced by the number of these molecules in food ingredients (Abe-Inge et al., 2018). Water absorption capacity is also influenced by the protein quality and the polar amino acid content, which has hydrophilic groups in the food (Affandi et al., 2020).

\section{Solubility}

Solubility is an important characteristic of seasoning since it will be added to a food product. Seasoning powder is expected to dissolve completely in food products (Andriani and Nurhartadi, 2014). According to Table 1 , the solubility of POFMT with a drying temperature of 55,60 , and $65^{\circ} \mathrm{C}$ was not significantly different. The solubility of POFMT with a drying temperature of 55,60 , and $65^{\circ} \mathrm{C}$ was $36.45,41.13$, and $42.33 \%$, respectively. In line with that, the drying of jack bean tempeh with different temperatures of 55,60 , and $65^{\circ} \mathrm{C}$ also did not significantly affect the solubility of the flour produced (Affandi et al., 2020).

Table 1. The physical characteristic of powdered over fermented mlanding tempeh

\begin{tabular}{lccc}
\hline \multicolumn{1}{c}{ Physical Characteristics } & \multicolumn{3}{c}{ Drying Temperature $\left({ }^{\circ} \mathrm{C}\right)$} \\
\cline { 2 - 4 } & 55 & 60 & 65 \\
\hline Yield $(\%)$ & $12.92^{\mathrm{D}} \pm 0.54$ & $10.37^{\mathrm{a}} \pm 3.28$ & $7.06^{\mathrm{a}} \pm 1.81$ \\
Water absorption $(\mathrm{g} / \mathrm{g})$ & $0.55^{\mathrm{a}} \pm 0.09$ & $0.45^{\mathrm{a}} \pm 0.09$ & $0.36^{\mathrm{a}} \pm 0.02$ \\
Solubility $(\%)$ & $36.45^{\mathrm{a}} \pm 3.84$ & $41.13^{\mathrm{a}} \pm 4.82$ & $41.33^{\mathrm{a}} \pm 4.14$ \\
Bulk density $(\mathrm{g} / \mathrm{mL})$ & $0.42^{\mathrm{a}} \pm 0.43$ & $0.43^{\mathrm{a}} \pm 0.05$ & $0.35^{\mathrm{a}} \pm 0.99$ \\
\hline
\end{tabular}

Note: Numbers with similar alphabets along the same line show no significant differences $(P>0.05)$ 


\section{Bulk density}

Bulk density is the mass of a material that fills a certain volume unit. It expresses the conciseness of material in occupying the volume. The greater the bulk density, the more concise the material occupies the same volume with a greater mass (Astawan et al., 2016). According to Table 1, the bulk density of POFMT was not significantly different for the three drying temperatures. The bulk density of POFMT with the drying temperatures of 55,60 , and $65^{\circ} \mathrm{C}$ was $0.42,0.43$, and $0.35 \mathrm{~g} / \mathrm{mL}$, respectively.

\section{Sensory evaluation}

Sensory evaluation was conducted to determine the panelists' preferences for the color, aroma, taste, and overall POFMT, dried at different temperatures.

\section{Color}

According to Table 2, the panelists' preferences for color had no significant differences in the three temperatures, 5.02 to 5.15. However, the highest score was drying temperature of $60^{\circ} \mathrm{C}$. According to the panelists, the POFMT color is a fairly light yellowish-brown. The brown color in POFMT is due to the color change during the continued fermentation of the tempeh. The study of Djunaidi et al. (2017) showed that the value of $L$ (lightness) decreased in the 72 hours overripe tempeh, between 48.96-56.9, compared to 24 hours overripe tempeh with an $L$ value of 72 . A lower $L$ value indicates a darker color. It is related to microbial growth; the color of immature mold is white, while the mature mold has a darker color. Due to the mold maturation, it lowers enzyme production and causes a darker color in overripe tempeh.

Table 2. Sensory evaluation of powdered over fermented mlanding tempeh

\begin{tabular}{lccc}
\hline \multirow{2}{*}{ Parameter } & \multicolumn{3}{c}{ Drying Temperature $\left({ }^{\circ} \mathrm{C}\right)$} \\
\cline { 2 - 4 } & 55 & 60 & 65 \\
\hline Color & $5.02^{\mathrm{a}}$ & $5.31^{\mathrm{a}}$ & $5.15^{\mathrm{a}}$ \\
Aroma & $4.50^{\mathrm{a}}$ & $4.71^{\mathrm{a}}$ & $4.52^{\mathrm{a}}$ \\
Taste & $4.33^{\mathrm{a}}$ & $4.35^{\mathrm{a}}$ & $4.31^{\mathrm{a}}$ \\
Overall & $4.42^{\mathrm{a}}$ & $4.60^{\mathrm{a}}$ & $4.56^{\mathrm{a}}$ \\
\hline
\end{tabular}

Note: Scoring scale $1=$ dislike very much; $2=$ dislike; $3=$ dislike slightly; $4=$ neither like nor dislike; $5=$ like slightly; $6=$ like; $7=$ like very much. Numbers with similar alphabets along the same column show no significant differences $(P>0.05)$

\section{Aroma}

According to Table 2, the panelists' preferences for aroma were not significantly different between three drying temperatures, namely between 4.50 and 4.52. However, the highest score was the drying temperature of $60^{\circ} \mathrm{C}$. The aroma formed in OFMT originates from compounds formed during fermentation, namely degradation of amino acid and forming ammonia with a characteristic pungent odor (Gunawan-Puteri et al., 2015; Hassanein et al., 2015). The pungent odor is also produced from fat hydrolysis (Hassanein et al., 2015).

\section{Taste}

According to Table 2, the panelists' preferences for the taste parameters of the three variations of the drying temperature were not significantly different, namely 4.31 to 4.35 . However, the highest score was the drying temperature of $60^{\circ} \mathrm{C}$. Besides, powdered over fermented mlanding tempeh had a savory or umami taste since the glutamic acid was 4.44 to $4.91 \%$. This glutamic acid was the highest amino acid content in POFMT (Table 3). Here, glutamic acid is an essential amino acid that contributes to umami flavor and has been used throughout the world to produce savory seasoning even though this flavor has been masked by fat or spice flavor (Gunawan-Puteri et al., 2015).

Table 3. The amino acid content of powdered over fermented mlanding tempeh

\begin{tabular}{lccc}
\hline \multirow{2}{*}{ Amino Acid } & \multicolumn{3}{c}{ Amino Acid Content (\% db) in } \\
& \multicolumn{3}{c}{ Various Drying Temperatures } \\
\cline { 2 - 4 } & $55^{\circ} \mathrm{C}$ & $60^{\circ} \mathrm{C}$ & $65^{\circ} \mathrm{C}$ \\
\hline L-Phenylalanine & 2.59 & 2.20 & 2.88 \\
L-Isoleucine & 1.88 & 1.55 & 1.84 \\
L-Valin & 2.13 & 1.82 & 2.14 \\
L-Arginine & 2.92 & 2.36 & 2.93 \\
L-Lysine & 2.91 & 2.57 & 2.78 \\
L-Leusin & 3.31 & 2.75 & 3.11 \\
L-Threonine & 1.75 & 1.54 & 1.95 \\
L-Histidin & 1.41 & 0.99 & 1.42 \\
L-Serine & 1.83 & 1.55 & 1.75 \\
L-Glutamic Acid & 5.50 & 5.05 & 5.43 \\
L-Alanin & 2.25 & 2.17 & 2.40 \\
Glisin & 1.94 & 1.68 & 2.04 \\
L-Aspartic acid & 3.79 & 3.46 & 3.73 \\
L-Tyrosine & 1.65 & 1.43 & 1.74 \\
L-Prolin & 1.47 & 1.34 & 1.35 \\
\hline
\end{tabular}

\section{Overall}

According to Table 2, the panelists' preferences as a whole signified no significant differences in the three drying temperatures with scores of 4.42 to 4.60. However, the highest score was the drying temperature of $60^{\circ} \mathrm{C}$.

\section{Amino acid content}

The amino acid in all POFMT was identified and quantified (Table 3 , the example of the obtained chromatogram is presented in Figure 1). Amino acids are building blocks compound of protein, divided into two groups, essential and non-essential amino acids. Table 3 presents the content of amino acids in the POFMT. The highest amino acid level was glutamic acid, followed by aspartic acid, about 14 and $10 \%$ of the 15 amino acids, respectively. 

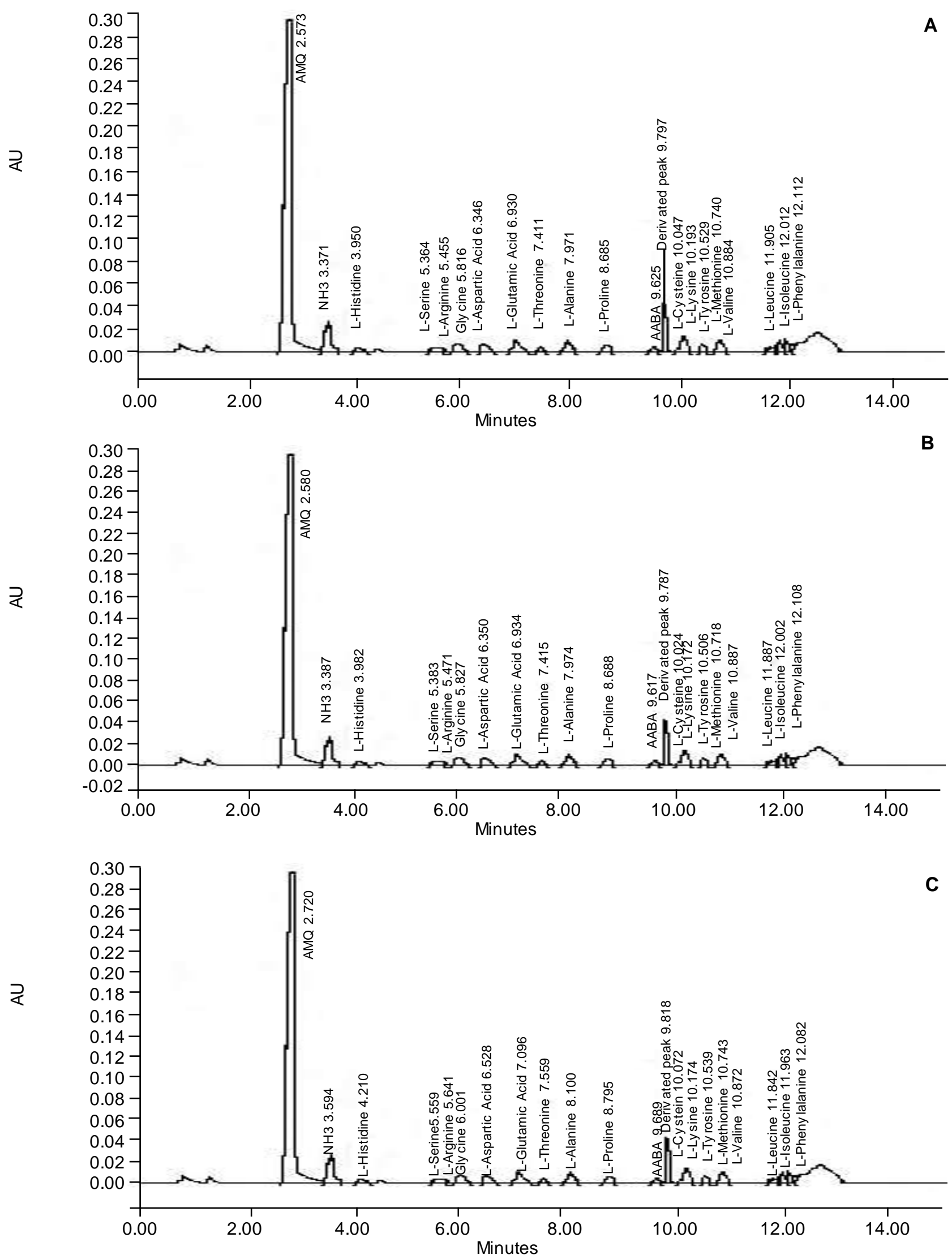

Figure 1. Amino acid profile chromatogram for powdered over fermented mlanding tempeh, dried in 55 (A), $60(\mathrm{~B})$, and $65^{\circ} \mathrm{C}(\mathrm{C})$. 
The glutamic acid content of POFMT, which was dried at 55,60 , and $65^{\circ} \mathrm{C}$, was $5.50,5.05$, and $5.43 \%$, respectively. Whereas aspartic acid content of POFMT dried at 55,60 , and $65^{\circ} \mathrm{C}$ were 3.79 , 3.46 , and $3.73 \%$, respectively. In this case, glutamic acid is crucial in forming umami (savory) taste and has long been used worldwide as savory seasoning. These results confirm that tempeh is a source of protein that can be used as an alternative to meat (Gunawan-Puteri et al., 2015).

The presence of glutamic acid as the dominant amino acid in powdered over fermented soybean tempeh also indicates its potential as a seasoning (Gunawan-Puteri et al., 2015). Likewise, it is potential in POFMT as a seasoning. The results align with the research conducted by GunawanPuteri et al. (2015) that in oven-dried overripe tempeh powder, the composition of glutamic acid and aspartic acids was 15.9 and $13.39 \%$.

In fermented products, glutamic acid is the highest level among the amino acids and contributes to the product's taste. Peptides consisting of hydrophilic amino acids (acidic), such as glutamic acid and aspartic acid in $\mathrm{N}$ terminals, have an umami taste. Besides, the taste of some fermented soybean food can be predicted by the free amino acid composition. The intensity of the umami taste can also be determined from the concentration of two acidic amino acids: glutamic acid and aspartic acid (Utami et al., 2016).

\section{CONCLUSION}

The research concludes that the different drying temperatures had a significant effect on yield and water absorption capacity but had no significant effect on the solubility and bulk density of the POFMT. The yield varied between $7.06-12.92 \%$, and the water absorption capacity varied between 0.36 $0.55 \mathrm{~g} / \mathrm{g}$. While the solubility of the POFMT varied between $36.45-41.33 \%$, the bulk density varied between 0.38-0.42 $\mathrm{g} / \mathrm{mL}$. However, the different drying temperatures did not significantly affect the panelist's preferences. In addition, the amino acid content of POFMT varied between $0.99-5.43 \%(\mathrm{db})$, with the two highest content being glutamic acid and aspartic acid. Therefore, POFMT indicates its potential as a seasoning.

\section{REFERENCES}

Andriani M, Anandito BK, Nurhartadi E. 2013. Pengaruh suhu pengeringan terhadap karakteristik fisik dan sensori tepung tempe "bosok". J Teknologi Hasil Pertanian 6: 95-102. DOI:
10.20961/jthp.Vio.13522.

Abe-Inge V, Agbenorhevi JK, Kpodo FM, Adzinyo OA. 2018. Effect of different drying techniques on quality characteristics of African palmyra palm (Borassus aethiopum) fruit flour. Food Res 2: 331-339.

Affandi DR, Ishartani D, Wijaya K. 2020. Physical, chemical and sensory characteristics of jack bean (Canavalia ensiformis) tempeh flour at various drying temperature. $2^{\text {nd }}$ International Conference and Exhibition on Power Technology (ICePTi) 2019, AIP Conference Proceedings 2219: 070004-1-070004-8. DOI: 10.10 63/5.0004674.

Andriani M, Anandito RBK, Nurhartadi E. 2014. Studies on physicochemical and sensory characteristics of overripe tempeh flour as food seasoning. Academic Res Int 5: 36-45.

Ariyantoro AR, Rachmawanti D, Ikarini I. 2016. Karakteristik fisikokimia tepung koro pedang (Canavalia ensiformis) termodifikasi dengan variasi konsentrasi asam laktat dan lama perendaman. Agritech 36: 1-6. DOI: 10.22146/agri tech. 10675 .

Astawan M, Wresdiyati T, Ichsan M. 2016. Karakteristik fisikokimia tepung tempe kecambah kedelai. J Gizi Pangan 11: 35-42.

Buwono MN, Amanto BS, Widowati E. 2018. Study of physical, chemical, and sensory characteristics of modified square banana flour (Musa balbisiana). Indonesian Food Nutr Prog 15: 3042. DOI: 10.22146/ifnp.33729.

Djunaidi S, Gunawan-Puteri MDPT, Wijaya $\mathrm{CH}$, Prabawati EK. 2017. Physicochemical and microbial characterization of overripe tempeh. INSIST 2: 48-51. DOI: 10.23960/ins.V2i1.33.

Duniaji AS, Wisaniyasa W, Puspawati NN, Indri HNM. 2019. Isolation and identification of Rhizopus oligosporus local isolate derived from several inoculum sources. Int $\mathrm{J}$ Curr Microbiol Appl Sci 8: 1085-1098. DOI: 10.20546/ijcmas. 2019.809.126.

Gunawan-Puteri MDPT, Hassanein TR, Prabawati EK, Wijaya CH, Mutukumira AN. 2015. Sensory characteristics of seasoning powders from overripe tempeh, a solid state fermented soybean. Procedia Chem 14: 263-269. DOI: 10.1016/j. proche.2015.03.037.

Handoyo T, Morita N. 2006. Structural and functional properties of fermented soybean (tempeh) by using Rhizopus oligosporus. Int J Food Prop 9: 347-355. DOI: 10.1080/10942910500224746. 
Hassanein TR, Prabawati EK, Gunawan-Puteri MDPT. 2015. Analysis of chemical and microbial change during storage of overripe tempeh powder as seasoning material. Int J Sci Eng 8: 131-134.

Kumalasari R, Setyoningrum F, Ekafitri R. 2015. Karakteristik fisik dan sifat fungsional beras jagung instan akibat penambahan jenis serat dan lama pembekuan. Pangan 24: 37-48.

Marand MA, Amjadi S, Marand MA, Roufegarinejad L, Jafari SM. 2020. Fortification of yogurt with flaxseed powder and evaluation of its fatty acid profile, physicochemical, antioxidant, and sensory properties. Powder Technol 359: 76-84. DOI: 10.1016/j.powtec.2019.09.082.

Ntau L, Sumual MF, Assa JR. 2017. Pengaruh fermentasi Lactobacillus casei terhadap sifat fisik tepung jagung manis (Zea mays saccharata Sturt)'. J Ilmu Teknol Pangan 5: 11-19.

Nursiwi A, Ishartani D, Sari AM, Nisyah K. 2018. Perubahan kadar protein, kadar serat, dan kadar fenol selama fermentasi tempe lamtoro (Leucaena leucocephala). Prosiding Seminar Nasional, Peran Keanekaragaman Hayati untuk Mendukung Indonesia sebagai Lumbung $\mathrm{Pa}$ ngan Dunia, Fakultas Pertanian UNS 2: F81-87.

Nursiwi A, Ishartani D, Sari AM, Nisyah K. 2018. Study on Leucaena leocochepala seed during fermentation: Sensory characteristic and changes on anti nutritional compounds and mimosine level. IOP Conference Series: Earth and Environmental Science, 102: 1-7. International Symposium on Food and Agrobiodiversity (ISFA) 2017, 26-27 September 2017, Semarang, Indonesia. DOI: 10.1088/1755-1315/102/1/012093.

Nwokocha LM, Williams PA. 2012. Rheological characterization of the galactomannan from $\mathrm{Leu}$ caena leucocephala seed. Carbohydr Polym
90: 833-838. DOI: 10.1016/j.carbpol.2012.06. 008.

Purbasari D. 2019. Aplikasi metode foam-mat drying dalam pembuatan bubuk susu kedelai instan. J Agroteknologi 13: 52-61. DOI: 10.19184/j-agt.v1 3i01.9253.

Syahrial S, Muchalal M. 2001. Isolation and identification of volatile components in tempe by simultaneous distillation-extraction method by modified extraction method. Indonesian $\mathrm{J}$ Chem 1: 63-72. DOI: 10.221 46/ijc.21945.

Triyono M, Nazaruddin, Werdiningsih W. 2017. Uji aktivitas inokulum tempe dari bahan limbah kulit pisang terhadap mutu tempe kedelai. Pro Food 3: 200-206. DOI: 10.29303/profood.v3i1.43.

Utami R, Wijaya $\mathrm{CH}$, Lioe HN. 2016. Taste of watersoluble extracts obtained from over-fermented tempe. Int J Food Prop 19: 2063-2073. DOI: 10.1080/10942912.2015.1104509.

Verma VK, Rani KV, Kumar SR, Prakash O. 2018. Leucaena leucocephala pod seed protein as an alternate to animal protein in fish feed and evaluation of its role to fight against infection caused by Vibrio harveyi and Pseudomonas aeruginosa. Fish Shellfish Immunol 76: 324332. DOI: 10.1016/j.fsi.2018.03.011.

Waters. 2012. Waters Acquity UPLC H Class and $\mathrm{H}$ Class Bio Amino Acid Analysis System Guide. 2012. Waters. USA

Wijaya $\mathrm{CH}$, Gunawan-Puteri MDPT. 2015. Tempe semangit, the overripe tempe with natural umami taste. Umami Indonesia 3: 1-5.

Zayed MZ, Sallam SMA, Shetta ND. 2018. Review article on Leucaena leucocephala as one of the miracle timber trees. Int J Pharm Pharm Sci 10: 1-7. DOI: 10.22159/ijpps.2018v10i1.18250. 